\title{
Relative nutritional value of whole protein, hydrolysed protein and free amino acids in man
}

\author{
K J MORIARTY, J E HEGARTY, P D FAIRCLOUGH, M J KELLY, M L CLARK, \\ AND A M DAWSON
}

\section{From the Department of Gastroenterology, St Bartholomew's Hospital, London}

SUMmARY To compare their effects on nitrogen balance, diets containing either lactalbumin whole protein, its peptide-rich enzymic hydrolysate or an equivalent mixture of free amino acids as the sole source of dietary nitrogen were fed to two healthy subjects, each studied for 38 days on two separate occasions. The nitrogen intake $(47 \mathrm{mg} / \mathrm{kg}$ body wt/day) induced a state of negative nitrogen balance, stimulating nitrogen conservation. Net daily nitrogen balance (mean $\pm \mathrm{SD}$ ) in subject 1 was $-0.23 \pm 0.72 \mathrm{~g}$ (amino acids) $v s+0.05 \pm 0.52 \mathrm{~g}$ (protein) and $-0.21 \pm 0.58 \mathrm{~g}$ (amino acids) $v s-0.05 \pm 0.57 \mathrm{~g}$ (hydrolysate), and in subject $2,-0.19 \pm 0.60 \mathrm{~g}$ (amino acids) $v s-0 \cdot 16 \pm 0.51 \mathrm{~g}$ (protein) and $-0.42 \pm 0.35 \mathrm{~g}$ (amino acids) $v s-0.62 \pm 0.34 \mathrm{~g}$ (hydrolysate). Analysis of these results by the cumulative sum technique showed no significant differences in the effect of the three nitrogen sources on nitrogen balance. This study indicates that there is no nutritional evidence to support the current practice of prescribing expensive enteral diets containing peptides or amino acids rather than the much cheaper whole protein to patients with normal gastrointestinal function.

Nitrogen absorption from the intestine occurs from a mixture of free amino acids and peptides liberated from ingested protein by the sequential action of pancreatic proteases and brush border membrane peptidases. Amino acids and small peptides are subsequently absorbed via specific free amino acid $^{1}$ and peptide ${ }^{2}$ transport systems located within the brush border membrane of mucosal enterocytes. The role of the intestinal peptide transport system in human dietary nitrogen absorption appeared to acquire nutritional importance when several studies in man showed that amino acids were absorbed to a greater extent from single peptides $^{34}$ and peptide containing protein hydrolysates than from equivalent mixtures of free amino acids. ${ }^{5-7}$ A subsequent study, however, has shown that, in the intestinal perfusion system used, the advantage conferred by the hydrolysate was concentration-dependent. ${ }^{8}$ Moreover, it has also been shown that plasma amino acid increments are similar when equivalent mixtures of free amino acids and peptides are fed to normal subjects. ${ }^{910}$

There are conflicting reports in the literature on the relative nutritional value of whole protein,

Address for correspondence: Dr Kieran J Moriarty, Department of Medicine, Hope Hospital, Salford M6 8HD.

Received for publication 15 August 1984. hydrolysed protein and free amino acids in man. ${ }^{11-13}$ As the confusion may be, at least in part, attributable to the fact that comparisons have been made between nitrogen sources of different amino acid compositions, we have compared the effects of whole protein, hydrolysed protein containing small peptides, and free amino acids, all with similar amino acid compositions, on nitrogen balance in normal man.

\section{Methods}

\section{COMPOSITION OF DIETS}

The diets contained either the milk protein lactalbumin (P), an enzymic hydrolysate of this protein $(\mathrm{H})$, or an equivalent mixture of free amino acids (AA) as the sole nitrogen source. The hydrolysate of lactalbumin was prepared by Nestlé Technical Assistance (Lausanne, Switzerland) as follows. Crude lactalbumin obtained from whey during the commercial processing of milk was hydrolysed with pancreatin. The resulting digest was separated into peptide fractions by ultrafiltration and the approximate size of the peptides obtained was estimated by gel filtration on columns of Sephadex G10. As estimated by this technique, the preparation contained $20 \%$ free 
amino acids, $30-35 \%$ di-, tri-, and tetrapeptides, 20-30\% larger oligopeptides up to molecular weight 1500 and $10-20 \%$ peptides above molecular weight 1500 . Because of the variation in the molecular weight of individual amino acids, this distribution is an approximation. The amino acid compositions of the nitrogen sources were estimated by ion-exchange chromatography using a Locarte amino acid analyser and are shown in Table 1. Energy was provided by a 1-4 $\alpha$ glucose polymer, Maxijul (Scientific Hospital Supplies, Liverpool, UK), and a fat emulsion of $50 \%$ arachis oil BP in water, Prosparol (Duncan Flockhart, Greenford, Middlesex, UK). Ribena (Beecham Products, Brentford, Middlesex, UK) was added for flavouring and the contents dissolved in water. The feeds contained recommended amounts of essential vitamins, minerals, and trace elements ${ }^{14}$ and were prepared in batches in the hospital diet kitchen. The diets were isocaloric ( $36 \mathrm{kcal} / \mathrm{kg}$ body weight/day) and isonitrogenous (47 mg nitrogen $/ \mathrm{kg}$ body weight/day). The glucose to nitrogen ratio was $340 \mathrm{kcal} / \mathrm{g}$ and energy to nitrogen ratio 762 $\mathrm{kcal} / \mathrm{g}$.

\section{EXPERIMENTAL DESIGN}

Two healthy volunteers, one man aged 47 years (subject 1), one woman aged 55 years (subject 2), were each studied under metabolic ward conditions on two separate occasions. The duration of each of

Table 1 Amino acid composition of the nitrogen sources (g/16g nitrogen)

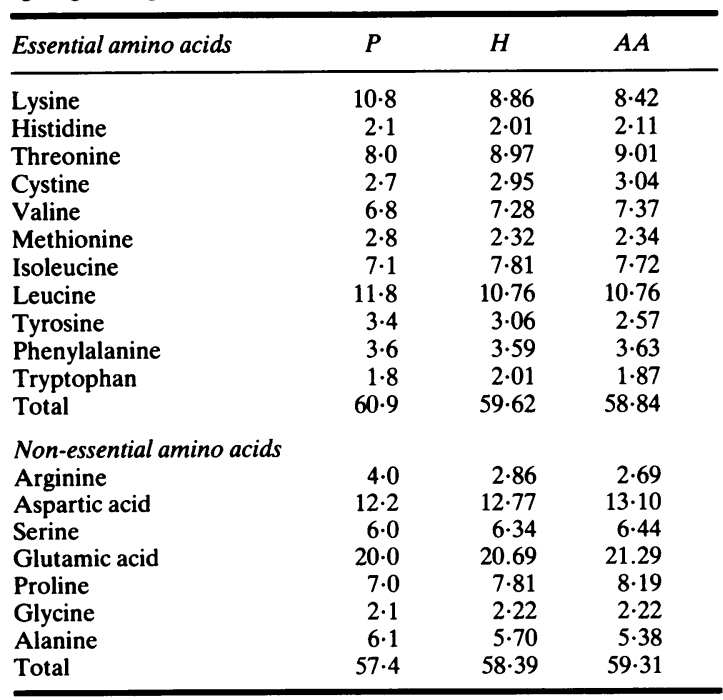

$P$ is lactalbumin whole protein, $\mathrm{H}$ its enzymic hydrolysate and AA the equivalent mixture of free amino acids. the four studies was 38 days. The diets fed to each subject are shown in Table 2 . The amino acid diet (AA) was first compared with an equivalent amount of protein $(\mathrm{P})$ and then with the peptidecontaining hydrolysate $(\mathrm{H})$ in each subject.

All urine passed during a 24 hour period was collected, the volume measured and aliquots stored at $-20^{\circ} \mathrm{C}$. Faeces were collected in pooled four or five day batches, weighed and homogenised with distilled water. Aliquots were freeze-dried in an Edward's EF03 freeze-drier (Edward's High Vacuum, Crawley, Sussex, UK) and stored at $-20^{\circ} \mathrm{C}$ until analysis. Total urinary and faecal nitrogen was measured in a fully automated nitrogen analyser. ${ }^{15}$ Nitrogen losses from the skin and miscellaneous sources were taken as $5 \mathrm{mg} / \mathrm{kg}$ body weight/day. ${ }^{16}{ }^{17}$ Subjects were weighed daily.

The study was approved by the Ethics Committee of St Bartholomew's Hospital and the nature of the study was fully explained to each volunteer.

\section{ANALYSIS}

The data were analysed by the cumulative sum (cusum) technique, ${ }^{18-20}$ which permits the detection both of a consistent sequential change in successive data from an arbitrary reference value which may be the mean of a selected group of those data, and also the time of onset of that change. In the present study, the mean net daily nitrogen balance for days 19-28 was chosen as the reference value. For each subject, the net daily nitrogen balance for each of the days 19-28 was entered into a computer, which stored the mean and standard deviation (SD). The data for days 29-38 were then entered and analysed consecutively, the computer subtracting the mean for days 19-28 from each of the values for the days 29-38 and accumulating the differences as the cusum as each additional datum was inserted. Therefore, in algebraic terms:

$$
C_{x}=C_{x-1}+b_{x}-m \text {, }
$$

where $C_{x}$ is the cusum for day $x, b_{x}$ is the nitrogen balance for day $x$, and $m$ is the mean net daily

Table 2 Nitrogen sources for each subject

\begin{tabular}{llll}
\hline Subject & $\begin{array}{l}\text { Period 1 } \\
\text { Day 1-14 }\end{array}$ & $\begin{array}{l}\text { Period 2 } \\
\text { Day 15-28 }\end{array}$ & $\begin{array}{l}\text { Period 3 } \\
\text { Day 29-38 }\end{array}$ \\
\hline 1 & P & AA & P \\
2 & AA & P & AA \\
1 & AA & H & AA \\
2 & H & AA & H \\
\hline
\end{tabular}

$\mathrm{P}$ is lactalbumin whole protein, $\mathrm{H}$ its enzymic hydrolysate and AA the equivalent mixture of free amino acids. 
nitrogen balance for days 19-28.

The cusums for days 29-38 for each subject were then plotted to give a cusum chart (Fig. 1). If the mean value of the net daily nitrogen balance for days $29-38$ is close to that for days $19-28$, some of the cusum increments will be positive and others negative, so that the cusum chart will be essentially horizontal. If the mean net daily nitrogen balance rises to a new constant value, however, more cusum increments will be positive, resulting in a line sloping upwards. Similarly, if the mean net daily nitrogen balance falls to a constant level, most cusum increments will be negative, giving a line sloping downwards. By superimposing a
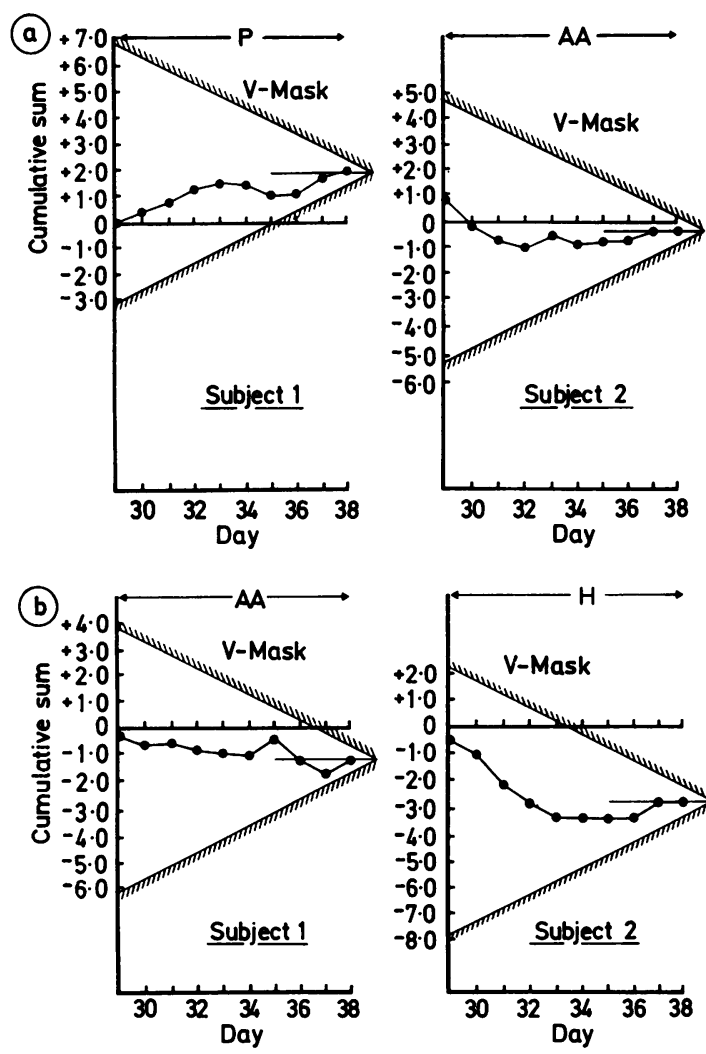

Fig. 1 Cumulative sum values (cusums) of the net daily nitrogen balance for days 29-38 for subjects 1 and 2. The amino acid mixture $(A A)$ is compared with lactalbumin whole protein $(P)$ in Fig. Ia and with the enzymic hydrolysate of lactalbumin $(H)$ in Fig. $1 b$. The V-mask is applied for day 38 in each subject. The cusums for days 29-38 in all four studies lie within the $V$-mask, except that in subject 2 , when comparing $A A$ with $H$, the cusums for days 29 and 30 lie above the $V$-mask inserted for days 31-33 (Fig. 1b). perspex V-shaped mask (V-mask) on the cusum chart with the vertex of the $\mathrm{V}$ pointing forwards and at a distance $d$ ahead of the most recent point on the chart, significant changes can be identified at the points where the cusums lie outside the Vmask. The V-mask is applied with the vertex at the same horizontal level as the previous day's cusum, but moved one day to the right, so that in Figure 1, the V-mask is shown in position for day 38 only. It was in fact applied for each of the days 29-38 for each subject in order to recognise significant changes in the cusum.

For significance tests, parameters are chosen so that the cusum cuts the edge of the V-mask with some predetermined $\alpha$ probability. ${ }^{18}$ We chose $\theta$, the angle between each limb of the V-mask and the horizontal as $26^{\circ} 34^{\prime}$, so that $\tan \theta=0 \cdot 5,{ }^{18}$ and $\mathrm{d}=1,{ }^{18}$ parameters which give an operating characteristic such that deviations of 2 SD's from the current mean would match an average cusum run length of two data points before cutting the boundary of the V-mask, and deviations of $1 \mathrm{SD}$ from the current mean would match an average cusum run length of five data points before the boundary is cut.

Using these parameters, the average run length if the null hypothesis is true is 19 days.

\section{Results}

The net daily nitrogen balance for subjects 1 and 2 fed protein and amino acids and hydrolysate and amino acids is shown in Figure 2. In all four studies, an initial period of marked negative nitrogen balance was followed by a period of reduced nitrogen wasting, so that during days 19-38, the day to day variations in nitrogen balance were small. Subject 1 took longer to adapt to the diet than subject 2 . The efficiency of nitrogen conservation was such that each subject achieved a positive nitrogen balance on a number of days despite the low nitrogen intake, although in general they were in negative balance. The mean net daily nitrogen balance for days 19-28 and 29-38 for each subject are shown in Table 3.

The cusums of the total net daily nitrogen balance for each of the days 29-38 for each subject are shown graphically in Fig. 1. For subject 1 , the substitution of protein for amino acids resulted in a cusum chart sloping slightly upwards except on days $34-35$, while in subject 2 , the change from protein to amino acids resulted in a cusum chart which sloped downwards from days 29-32, but was thereafter horizontal. When the V-mask was applied for subjects 1 and 2, all of the cusums for days 29-38 lay within its limbs (Fig. 1a). Thus the 


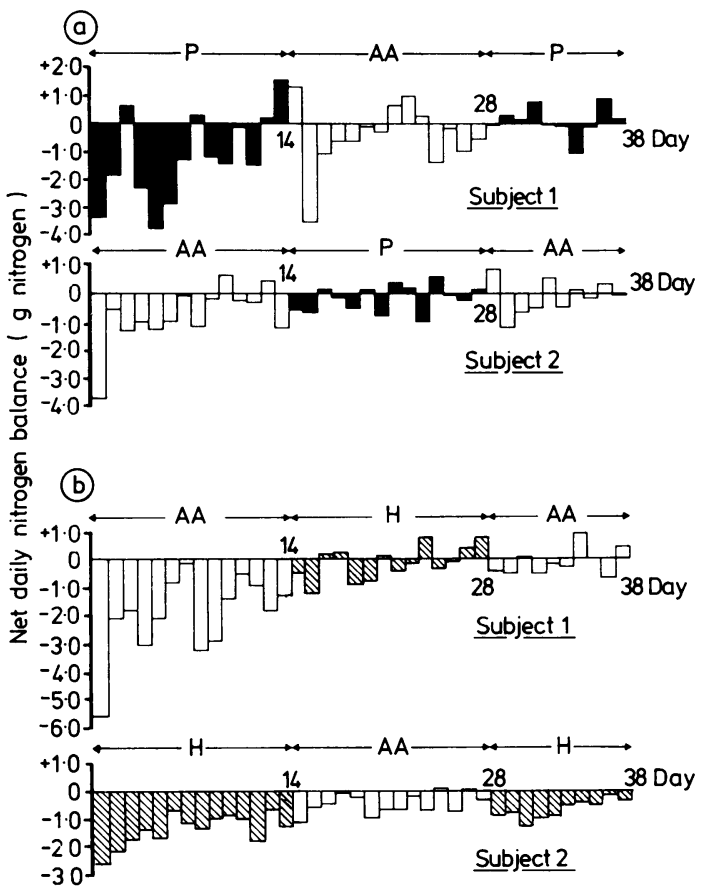

Fig. 2 Net daily nitrogen balance in subjects 1 and 2 during the feeding of an equivalent amino acid mixture $(A A)$ and either lactalbumin whole protein $(P)$ or the enzymic hydrolysate of lactalbumin $(H)$. AA (open columns), $P$ (shaded columns), $H$ (hatched columns).

substitution of protein for amino acids in subject 1 at day 29 and vice versa in subject 2 resulted in no significant change in the net daily nitrogen balance. In subject 1 , the overall slope of the cusum chart was slightly downwards on changing from hydrolysate to amino acids (Fig. 1b). However, when the V-mask was applied, none of the cusums for days 29-38 fell outside its limbs, showing that there was no significant difference between hydrolysate and amino acids. In subject 2 ,

Table 3 Mean net daily nitrogen balance for each subject

\begin{tabular}{lll}
\hline Subject & Days $19-28$ & Days $29-38$ \\
\hline 1 & $-0 \cdot 23 \pm 0 \cdot 72(\mathrm{AA})$ & $+0 \cdot 05 \pm 0 \cdot 52(\mathrm{P})$ \\
2 & $-0 \cdot 16 \pm 0 \cdot 51(\mathrm{P})$ & $-0 \cdot 19 \pm 0 \cdot 60(\mathrm{AA})$ \\
1 & $-0.05 \pm 0 \cdot 57(\mathrm{H})$ & $-0 \cdot 21 \pm 0.58(\mathrm{AA})$ \\
2 & $-0 \cdot 42 \pm 0.35(\mathrm{AA})$ & $-0 \cdot 62 \pm 0.34(\mathrm{H})$ \\
\hline
\end{tabular}

Results are mean \pm SD of the mean net daily nitrogen balance (g) for each period. $+=$ positive,$-=$ negative nitrogen balance. $P$ is lactalbumin whole protein, $\mathrm{H}$ its enzymic hydrolysate and AA the equivalent mixture of free amino acids. in whom the order of feeding hydrolysate and amino acids was reversed, the slope of the cusum chart was downwards during days 29-33, but from days 33-38, the line was horizontal with a little bit of 'up'. The differences between hydrolysate and amino acids achieved statistical significance only on days 31-33. With the V-mask applied for each of these days, the cusums for days 29 and 30 lay above its upper limb, indicating that this subject was in significantly greater negative nitrogen balance for days 31-33 when ingesting hydrolysate than when consuming amino acids during days 19-28. ${ }^{17}$ With the V-mask applied for days $34-38$, however, the cusum values all lay within its limbs (Fig. 1b). Thus the significant change was not maintained and the net daily nitrogen balance on hydrolysate for days 34-38 was not significantly different from that on amino acids for days 19-28.

In subject 1 , the loss of body weight during the study period on protein was $1.4 \mathrm{~kg}$ and on amino acids $1.55 \mathrm{~kg}$. When hydrolysate was compared with amino acids in this subject, the figures were $2 \cdot 1 \mathrm{~kg}$ and $2 \cdot 1 \mathrm{~kg}$ respectively. In subject 2 , body weight was constant during the comparison of amino acids with both protein and hydrolysate.

\section{Discussion}

The present study showed that there were no significant differences in nitrogen balance over the 10-day study periods taken as a whole in normal healthy subjects fed lactalbumin whole protein, its enzymic hydrolysate and a mixture of free amino acids of similar composition. The three nitrogen sources were also equivalent in their ability to maintain body weight.

The amino acid compositions of protein, hydrolysate and amino acids were equivalent. The nitrogen intake $(47 \mathrm{mg} / \mathrm{kg}$ body weight/day), which is equivalent to a $20 \mathrm{~g}$ protein diet for a $70 \mathrm{~kg}$ man, was chosen to induce a state of negative nitrogen balance, and to stimulate nitrogen conservation. It seems likely that under these conditions of nitrogen wasting, urinary nitrogen excretion reflects tissue metabolism rather than hepatic urea synthesis, which would permit the detection of subtle differences in the nutritional value of different nitrogen sources. The glucose polymer and fat emulsion each provided approximately $40-45 \%$ of the daily energy intake, while the nitrogen source and ribena contributed the remaining $15 \%$. Although the energy to nitrogen ratio was higher than has been suggested for optimal utilisation of nitrogen, ${ }^{22}$ this was necessitated by the requirement for a low nitrogen intake. 
The protocol was designed to incorporate a 14 day adaptation period to the liquid-defined formula diets. ${ }^{23}$ Statistical comparisons of the net daily nitrogen balance for days 19-28 with that for days 29-38 allowed for both the adaptation period and for the changeover in nitrogen sources at day 15. The results were analysed by the cusum technique, the appropriate test for detecting a significant change in the mean value of a process and for determining whether this change coincides with alterations in treatment. ${ }^{1820}$ By applying the cusum technique, it was evident that there were no significant differences in the effects of protein and amino acids on nitrogen balance in either subject. In the comparison of hydrolysate to amino acids, nitrogen conservation tended to be better on hydrolysate in subject 1 and on amino acids in subject 2 , and although statistically significant differences were observed on three days in subject 2 , these were not maintained.

As no significant differences in the effects on nitrogen balance of the three nitrogen sources have been detected, it might be argued that significant effects could have been missed through small data numbers, which would lead to the acceptance of a false null hypothesis. While the possibility that statistically significant differences might have appeared in more prolonged experiments cannot be excluded, the biological difference involved would then be extremely small. It should also be emphasised that only two subjects were studied on two separate occasions for what in statistical terms amounts to a relatively short time. In the context of nitrogen balance studies in man, however, these are reasonably prolonged studies. Therefore, while care should be taken not to generalise too far from the present observations, the fact that no overall differences in nitrogen balance were found in any of the four studies makes it highly unlikely that any nutritional difference between the three sources of dietary nitrogen has been missed.

Previous studies have examined the effect of whole protein, peptides and amino acids on nitrogen balance and growth in both animals and man. Comparison of the growth-promoting properties of casein and free amino acids in rats has shown the protein to be variously superior ${ }^{24}$ or equivalent ${ }^{25}$ to the amino acid preparation. In the same respect, a casein hydrolysate proved either equivalent $^{24}$ or inferior ${ }^{26}{ }^{27}$ to casein itself. Rose noted that human subjects required more calories to maintain nitrogen balance when fed an acid hydrolysate of casein than when they received casein itself. They needed an even higher energy intake when fed an amino acid mixture of similar composition to casein. ${ }^{11}$ Recently, the whole protein, Clinifeed 400 (Roussel Laboratories Ltd, Roussel House, Middlesex, UK) and the free amino acid preparation, High Nitrogen Vivonex (Norwich-Eaton Pharmaceuticals, Norwich, NY) proved equally effective in preserving the nutritional status of patients with normal gastrointestinal function. ${ }^{12}$ In patients with Crohn's disease and malabsorption, however, the peptidecontaining preparation, Criticare-HN (Mead Johnson Nutritional Division, Evansville, Ind), appeared to promote better nitrogen retention than either High Nitrogen Vivonex or solid food. ${ }^{13}$ Whole protein, peptides and amino acid mixtures, however, compared in the above studies, were not equivalent with respect to their amino acid compositions. In particular, High Nitrogen Vivonex has a high content of glutamine, which is absent from both Criticare-HN and Clinifeed 400. It is possible that the amino group of glutamine is a source of urea production after its metabolism through the Kreb's cycle in the liver, which may explain the increased urinary urea excretion in patients fed High Nitrogen Vivonex when compared to Clinifeed $400^{12}$ and Criticare-HN. ${ }^{13}$ The conclusion drawn from this latter study was that High Nitrogen Vivonex had a lower biological value than Criticare-HN. ${ }^{13}$ This interpretation must be regarded with caution, however, in view of the finding that High Nitrogen Vivonex proved nutritionally equivalent to Clinifeed 400 despite the increased nitrogen excretion on the former diet. $^{12}$

The present study shows that lactalbumin whole protein, its enzymic hydrolysate and an equivalent mixture of free amino acids have comparable effects on nitrogen balance and body weight in normal subjects and should help to resolve the 'considerable uncertainty about whether mixtures of amino acids corresponding to the composition of proteins are nutritionally equivalent to the proteins themselves'.28

If the results with lactalbumin are confirmed for other proteins, then there is no nutritional logic in the current practice of prescribing expensive enteral feeds containing specialised nitrogen sources such as amino acids or peptides to patients with normal gastrointestinal function, who form the majority of patients who are fed through the enteral route. Further studies using nitrogen preparations of comparable amino acid composition are required to establish whether there are any nutritional advantages in using free amino acids or peptides rather than whole protein in patients with compromised gastrointestinal function, such as short bowel syndrome, malabsorption or pancreatic insufficiency. 
We are indebted to Professor D W Vere, Professor of Therapeutics at the London Hospital, Whitechapel, London, for his invaluable help in the application of the cumulative sum technique and the use of the computer programme, to Professor $\mathrm{M} \mathrm{H}$ Irving and his staff in the Department of Surgery at Hope Hospital, Salford, for the use of their nitrogen analyser, to Mrs L Daniels, Miss S Evans and the Dietetic Department at St Bartholomew's Hospital for preparing the diets and to Nestlé, Lausanne, Switzerland for financial support and for providing the lactalbumin preparations.

KJM was in receipt of a Medical Research Council Training Fellowship. MJK was supported by the Joint Research Board, St Bartholomew's Hospital.

\section{References}

1 Gray GM, Cooper HL. Protein digestion and absorption. Gastroenterology 1971; 61: 535-44.

2 Matthews DM. Intestinal absorption of peptides. Physiol Rev 1975; 55: 537-608.

3 Adibi SA, Phillips E. Evidence for greater absorption of amino acids from peptide than from free form in human intestine. Clin Res 1968; 16: 446.

4 Adibi SA. Intestinal transport of dipeptides in man: relative importance of hydrolysis and intact absorption. J Clin Invest 1971; 50: 2266-75.

5 Silk DB, Marrs TC, Addison JM, Burston D, Clark ML, Matthews DM. Absorption of amino acids from an amino acid mixture simulating casein and a tryptic hydrolysate of casein in man. Clin Sci 1973; 45: 715-9.

6 Silk DB, Marrs TC, Clegg KM, et al. Jejunal absorption of an amino acid mixture simulating casein and an enzymic hydrolysate of casein prepared for oral administration to normal adults. Br J Nutr 1975; 33: $95-100$.

7 Fairclough PD, Hegarty JE, Silk DB, Clark ML. Comparison of the absorption of two protein hydrolysates and their effects on water and electrolyte movements in the human jejunum. Gut 1980; 21: 829-34.

8 Hegarty JE, Fairclough PD, Moriarty KJ, Kelly MJ, Clark ML. Effects of concentration on in vivo absorption of a peptide containing protein hydrolysate. Gut 1982; 23: 304-9.

9 Silk DBA, Chung YC, Berger KL, et al. Comparison of oral feeding of peptide and amino acid meals to normal human subjects. Gut 1979; 20: 291-9.

10 Hegarty JE, Fairclough PD, Moriarty KJ, Clark ML, Kelly MJ, Dawson AM. Comparison of plasma and intraluminal amino acid profiles in man after meals containing a protein hydrolysate and equivalent amino acid mixture. Gut 1982; 23: 670-4.
11 Rose WC, Coon MJ, Lambert GF. The amino acid requirements of man. VI The role of the caloric intake. J Biol Chem 1954; 210: 331-42.

12 Jones BJM, Lees R, Andrews J, Frost P, Silk DBA. Comparison of an elemental and polymeric enteral diet in patients with normal gastrointestinal function. Gut 1983; 24: 78-84.

13 Smith JL, Arteaga C, Heymsfield SB. Increased ureagenesis and impaired nitrogen use during infusion of a synthetic amino acid formula. $N$ Engl J Med 1982; 306: 1013-8.

14 National Research Council, Food and Nutrition Board. Recommended dietary allowances. 9th ed. Washington, DC: National Academy of Sciences, 1980.

15 Holbrook IB. Evaluation of an automated nitrogen analyser in the clinical laboratory. $\mathrm{Br} J$ Clin Equip 1979; 4: 62-6.

16 Sirbu ER, Margen S, Calloway DH. Effect of reduced protein intake on nitrogen loss from the human integument. Am J Clin Nutr 1967; 20: 1158-65.

17 Calloway DH, Odell ACF, Margen S. Sweat and miscellaneous nitrogen losses in human balance studies. J Nutr 1971; 101: 775-86.

18 Woodward RH, Goldsmith PL. Cumulative sum techniques. ICI statistical monographs no. 3. Edinburgh; Oliver and Boyd, 1967: 1-18.

19 Chaput de Saintonge DM, Vere DW. Why don't doctors use cusums? Lancet 1974; 1: 120-1.

20 Zeegen R, Drinkwater JE, Fenton JCB, Vince A, Dawson AM. Some observations on the effects of treatment with lactulose on patients with chronic hepatic encephalopathy. $Q J$ Med 1970; 39: 245-63.

21 Waterlow JC. Observations on the mechanism of adaptation to low protein intakes. Lancet 1968; 2: 1091-7.

22 Department of Health and Social Security. Recommended intakes of nutrients for the United Kingdom. London, HMSO, 1976; 4-16.

23 Spiller GA, Beigler MA. Time-dependent gastrointestinal adaptation of human subjects and nonhuman primates to liquid defined formula diets. Z Ernaehrungswiss [Suppl] 1977; 20: 48-57.

24 Ramasarma GB, Henderson LM, Elvehjem CA. Purified amino acids as a source of nitrogen for the growing rat. J Nutr 1949; 38: 177-94.

25 Sauberlich HE. Growth of rats fed protein-free diets supplemented with purified amino acid mixtures. $J$ Nutr 1961; 74: 298-306.

26 Woolley DW. Observations on the growth-stimulating action of certain proteins added to protein-free diets compounded with amino acids. J Biol Chem 1945; 159: 753-4.

27 Woolley DW. Some correlations of growth-promoting powers of protein with their strepogenin content. $J$ Biol Chem 1946; 162: 383-8.

28 Matthews DM, Payne JW. Nutrition of microorganisms and animals. In: Matthews DM, Payne JW, eds. Peptide transport in protein nutrition. Amsterdam, North-Holland, 1975: 51. 